\title{
EQUITY, NOTICE AND FRAUD IN THE TORRENS SYSTEM
}

\section{G. J. DAVIES*}

The Torrens land system has been adopted in many jurisdictions, including Australia, Canada and New Zealand, as a substitute for the old common law and equity system of land transfer. The various Torrens Acts of these jurisdictions contain sections purporting to eliminate the equitable doctrine of notice. The author suggests that although these sections are virtually identical their application has varied. The courts of Australia, the Supreme Court of Canada and the courts of Saskatchewan have applied the sections literally to allow registration of a transfer to defeat an unregistered interest even though at the time of contracting to purchase the transferee knew of the unregistered interest and that his registration would defeat or prejudice it. On the other hand, the courts of New Zealand, British Columbia, Manitoba and Alberta have viewed notice, at least when accompanied by an intention to defeat a prior unregistered interest, as sufficient in itself in some cases to constitute fraud upon that interest. The author contends that the sections were intended to keep fraud and notice distinct and that the doctrine of notice should be eliminated in order to achieve security of title. Registration under the Torrens system was intended to provide ultimate protection against other interests. Where it is not possible to effect registration immediately upon the acquisition of an interest, as is generally the case, the caveat provisions of the various Acts are intended to be and should be utilized to protect that interest, thus eliminating the need for the protection provided previous to the Acts by the doctrine of notice.

Recently, in an article reviewing the working of the Torrens system in New South Wales after one hundred years of operation, Roy A. Woodman was moved to make the following statement: ${ }^{1}$

After more than one hundred years of the Torrens system, there is no need to labour the principle that upon registration, the registered proprietor holds his estate free from any trusts or unregistered interests of which he had notice before registration..., or of which he receives notice after registration, provided that his title is not affected by fraud: s. 43 specifically provides that the knowledge of any trust or unregistered interest and shall not of itself be imputed as fraud.

He cites a number of cases which illustrate "... [t]hat the Act, in this regard, really means what it says." 2

No exception can be taken to that quotation as a statement of the position taken by Australian courts in general and New South Wales courts in particular towards the doctrines of notice and fraud within the Torrens system. However, that same view has not been so firmly adhered to in all jurisdictions which have adopted what can be termed Torrens systems of registration of title to land. It is interesting, therefore, to compare and contrast the attitudes taken in some of those jurisdictions and to seek to determine which view most nearly achieves the purposes underlying the legislation.

The Torrens Acts of the Australian states, the provinces of Western Canada, and of New Zealand all contain sections purporting to relieve

\footnotetext{
- B.A., LL.M., Lecturer in Law, Australian National University.

1 The Torrens System in New South Wales-One Hundred Years of Indefeasibility of Title, (1970) 44 Australian Law Journal 96 at 105

I Id.
} 
takers of registered interests in land under those Acts from the effect of notice of trusts and unregistered interests. ${ }^{3}$ The various sections are not all identical in wording but they all contain the same basic principles, unless the omission of certain words and phrases in the British Columbia and Queensland provisions is to be taken to result in the enactment of different principles. ${ }^{4}$ The most common form of words is as follows: ${ }^{5}$

\begin{abstract}
Except in the case of fraud no person contracting or dealing with or taking or proposing to take a transfer from the registered proprietor of any registered estate or interest shall be required or in any manner concerned to enquire or ascertain the circumstances in or the consideration for which such registered owner or any previous registered owner of the estate or interest in question is or was registered, or to see to the application of the purchase money or any part thereof, or shall be affected by notice direct or constructive of any trust or unregistered interest, any rule of law or equity to the contrary notwithstanding; and the knowledge that any such trust or unregistered interest is in existence shall not of itself be imputed as fraud.
\end{abstract}

The imporant points are that neither direct nor constructive notice of trusts or unregistered interests is to affect persons who come within these sections; fraud is an express exception to the protection provided, except in British Columbia and, with the exception of the British Columbia and Queensland provisions, it is expressly stated that knowledge of the existence of such interests shall not of itself be imputed as fraud. Despite the basic similarity of the sections the interpretations placed upon them by courts in the different jurisdictions has varied greatly from the earliest days of the introduction of the Torrens system of title. Even where the variation in interpretation has not been great the practical results of the application of the sections have differed considerably.

The Australian courts, the Supreme Court of Canada and the courts of Saskatchewan have tended to give the fullest effect to the words of the respective section, thus largely excluding the doctrine of notice from the Torrens system. The courts of Alberta, British Columbia, Manitoba and especially New Zealand have been less inclined to discard the equitable principles. In respect of New Zealand, Dr. D. Kerr observed in 1927 that there had been a greater tendency to lean towards the dispossessed person than in Australia. ${ }^{6}$ Cases decided in New Zealand more recently suggest, with one possible exception, that the tendency, in so far as protection from notice is concerned, is still present. ${ }^{7}$ There have not been many cases on this point in Western Canada in recent years but, as the decided cases stand, it would appear that the courts outside of Saskatchewan are inclined more towards

\footnotetext{
+ Real Property Act, 1900-1970 (N.S.W.), s. 43; Transfer of Land Act, 1958 (Vic.), 8. 43; Real Property Act, 1886 - 1969 (S.A.), 8s. 186, 187; Real Property Act, 1861 - 1963 (Q1d). 8. 109; Transfer of Land Act, 1893 - 1969 (W.A.), s. 134; Real Property Act, 1862 - 1966 (Tas.) s. 114; The Land Titles Act, R.S.A 1970 , c. 198, 8. 203; Land Registry Act, R.S.B.C. 1960, c. 208, 8. 44(1); The Real Property Act. R.S.M. 1970, c. R.30, 8. 81; The Land Titles Act, R.S.S. 1965, c. 115, 8. 231; Land Transfer Act, 1952 (N.Z.) 8. 182.

Infra, at 116, n. 62 .

s The sections in the Acts of Alberta, Manitoba, Saskatchewan, New South Wales, Victora and New Zealand are precisely similar.

- The Principles of the Australian Land Titles (Torrens) System, at 216.

7 Webb v. Hooper [1953] N.Z.L.R. 111; Harris v. Fitzmaurice [1956] N.Z.L.R. 975; c.f. Ruapekapeka Sawmill Co. Ltd. v. Yeatts and Another [1958] N.Z.L.R. 265. Sec also Adams, The Land Transfer Act, 1952.
} 
the New Zealand than the Australian approach. ${ }^{8}$ As mentioned earlier, the Supreme Court of Canada has given the section full weight ${ }^{9}$ but, because every case of alleged fraud must "depend upon its own circumstances,"10 the effect to be attributed to notice is perhaps still an uncertain matter in Western Canada, except in Saskatchewan. Certainly, it was suggested as recently as 1966 that the Alberta section had not been given its full effect by any Alberta court. ${ }^{11}$

Basically the attitude of the Australian and Saskatchewan courts has been that the sections allow registration of a transfer to defeat an unregistered interest even though at the time of contracting to purchase the transferee knew of the unregistered interest. ${ }^{12}$ Indeed in Munro v. Stuart, a New South Wales decision, even the fact that it had been the transferee's intention throughout to defeat unregistered tenancies granted by the previous registered proprietor did not deter Harvey J. from applying the section to protect the transferee. ${ }^{13}$ Neither the Australian nor the Saskatchewan courts have attempted to deny that fraudulent transferees are excepted from the protection afforded by the section, but it will be seen that they have required something more positively dishonest than the New Zealand courts and the courts of the other provinces of western Canada before holding that fraud has been shown.

A complete definition of "actual fraud" has not been attempted in any of the reported cases but instances of what might be treated as fraud have been adverted to. For example, actual fraud is said to be present where there is collusion between the transferor and transferee to defeat an equitable interest and where the transferee acts to induce a person having an equitable interest not to enforce his right nor to lodge a caveat. ${ }^{14}$ But in Australia and Saskatchewan, mere disregard of unregistered rights of which a transferee has notice is not fraudu-

\footnotetext{
8 See cases discussed infra at 113-115. It must be conceded that Re Pacific United Developers (1962) Ltd. (1965) 51 D.L.R. (2d) 93, a case decided in the Supreme Court of British Columbia, goes against this. There it was said that registration with notice of a prior unregistered sale agreement would not constitute fraud. It was clearly stated that mere notice is not fraud. However, it is submitted that the force of the judgment is diminished somewhat by the fact that the time for completion of the prior agreement was well past and therefore the assumption that it was no longer in force was reasonable. Furthermore Munroe $J$. supported his statement that mere notice does not, per se, constitute fraud by reference to Waimiha Sawmilling Co. Ltd. v. Waione Timber Co. Ltd. [1926] A.C. 101, [1925] 3 W.W.R. 95 and Graveling v. Graveling [1950] 2 D.L.R. 308, 340, [1950] 1 W.W.R. 574.

As pointed out in the text, infra, at 111-112, the Waimiha case can be and has been taken to support those who argue for limited view of the effect of the notice section as well as those who take a wide view of it. Then the passages referred to in Greveling v. Greveling cast doubt upon the force to be attributed to Munroe J.'s assertion that mere notice does not constitute fraud as they contain a question from Lord Lindley's judgment in the Privy Council hearing of Assets Co. v. Mere Raihi [1905] A.C. 176, 210 where it is said that a man who fails to make inquiries after his suspicions have been aroused as to the existence of a prior interest is guilty of fraud.

Lastly in Greveling v. Greveling some reliance was placed upon Ruthenian Greek Catholic Church v. Fetsyk [1922] 3 W.W.R. 872, 879 and Sydie v. Saskatchewan and Battle River Land Development Co. (1913) 14 D.L.R. 57. These cases do not support the giving of full effect to the notice section.

9 Boulter-Waugh \& Co. Ltd. v. Phillips and Union Bank [1919] I W.W.R. 1046, 58 S.C.R. 385, 46 D.L.R. 41.

10 Waimiha Sawmilling Co. v. Waione Timber Co. [1926] A.C. 101 at 106-107.

" (1966) 4 Alta. L. Rev. 488 at 491.

12 Robertson v. Keith (1870) I V.R. Eq. 11; Couke v. The Union Bank (1893) 14 N.S.W.R. (Eq.) 280; Oertel v. Hordern (1902) 2 S.R. (N.S.W.) Eq. 37; Rounsevell v. Ryan \& Sons [1910] S.A.L.R. 67; Wicks v. Bennett (1921) 30 C.L.R. 80; Munro v. Stuart (1924) 41 S.R. (N.S.W.) 203; Hackworth v. Baker [1936] 1 W.W.R. 321; Pfeiffer v. Pfeiffer [1950] 2 W.W.R. 1227; Canadian Superior Oil v. Cugnet (1954) 12 W.W.R. (N.S.) 174; T. M. Ball Lumber Co. v. Zirtz (1960) 24 D.L.R. (2d) 284 (subsequently reversed on a different point in a decision in which Hackworth v. Baker is distinguished-(1961) 27 D.L.K. (2d) 557; Bensette v. Reece [1969] 70 W.W.R. 706. See also R. Carter, Some Reflections on the Land Titles Act of Saskatchewan, (1965) 30 Sask. Bar Rev. 315.

i. Id.

"Robertson v. Keith (1870) 1 V.R. Eq. 11 at 14; Oertel v. Hordern (1902) 2 S.R. (N.S.W.) Eq. 37 at 46, 47: Zbryski v. Cily of Calgary (1965) 51 D.L.R. (2d) 54.
} 
lent. ${ }^{15}$ Furthermore, in denying effect to notice of unregistered interests Harvey J., in Munro v. Stuart, said that the section draws no distinction between knowledge of the existence of an unregistered interest and knowledge of its nature. ${ }^{16}$ However, some caution must be shown in making generalizations about the attitude of the Australian courts, ${ }^{17}$ and in Union Bank of Canada and Phillips v. Boulter-Waugh ${ }^{18}$ it was necessary for the Supreme Court of Canada to reverse the judgment of the Saskatchewan Court of Appeal in order to disestablish the equitable doctrine of notice in that province. Nevertheless, it can be said that Mr. Woodman's statement can now be safely applied to Australia and Saskatchewan.

In New Zealand the attitude of the courts, as mentioned previously, has been rather different. The courts have acknowledged that the section evidences a clear intention to alter the rule of equity which postpones the interest of a purchaser for value, even of the legal estate, to prior interests of which he had notice before he paid his purchase money. ${ }^{19}$ It has been conceded that the section narrows down the class of cases in which fraud is imputable to a purchaser to cases of actual fraud involving dishonesty; thus denying the operation of the doctrine of constructive notice in the New Zealand Torrens system. ${ }^{20}$ However, it has also been stated that it was not the intention of the Legislature to "confer immunity in all cases on purchasers who are guilty of what in reference to transactions of this nature has been considered as fraud." 21

At this point the New Zealand courts have diverged from the path travelled by the Australian courts. Because the section has been seen not to "confer immunity in all cases" there has arisen the problem of determining the limits of operation of the section. As is usual the extreme situations cause little difficulty. Where a purchaser acts in collusion with his vendor to defraud the holder of an unregistered interest by trickery, he is clearly fraudulent. Equally clearly he is not fraudulent where he has but "a mere hint of some possible irregularity."22 The difficulty as Richmond J. said in National Bank v. National Mortgage and Agency Co. ${ }^{23}$ is to determine at what point to draw the line. Richmond J. sidestepped the difficulty by saying that the case fell on the fraud side of any line he might have drawn. Fraud was established in that case by the fact that the registered mortgagee, a bank, had direct notice through its agent, a branch bank manager, not only of the existence of a trust over the mortgaged property but also of its terms. The significant point being that it had notice that the

\footnotetext{
1: Wicks v. Bennett (1921) 30 C.L.R. 80 at 91, per Knox C.J. and Rich J.; Boulter.Waugh \& Co. Ltd. v. Phillips and Union Bank, supra, n. 9; Hackuorth v. Baker, Canadian Superior Oil v. Cugnet, supra, n. 12. 11. (1924) 41 S.R. (N.S.W.) 203 at 20 i.

1: Isaacs $\mathrm{J}$. in Butler v. Fairclough appenred to support the New Zealand approach and laid emphasis on words "of itself" in the section. His Honour also referred to the judgment of Boucat J. in Franklin v. Ind, an earlier Australian decision, as supporting this view. However, the latter case was one in which the vurchasers not only knew of the existence of a lease but purchased subject to it. Note also Higgins J. in Wicks v. Bennett. However, these cautionary dicta stand on their own in Australia. Compare Independent Lumber Co. v. Gardiner [1910] 3 S.L.R. 140.

is (1919) 46 D.L.K. 41.

19 National Bank v. National Mortgage and Agency (v; Vincent (Inter-pleader claimant) (1885) N.Z.L.R. 3 S.C. 257 at $262-263$.

20 Id. and numerous other cases.

$\therefore$ Id.

$\therefore$ Supra, n. 19 at 264 .

$\therefore$ Supra, n. 14.
} 
trustees had, by reason of the terms of the trust, no power to effect the mortgage that was being given. Richmond $J$. said that it was a case of a purchaser taking with full knowledge that the transfer to himself would unjustly deprive the true owner of his property without adequate compensation. ${ }^{24}$

In later cases it has been held that a transferee is guilty of fraud where he becomes registered with the certain knowledge of the existence of an adverse right which will be destroyed by his registration. ${ }^{25}$ And the case against him is even stronger if it is his intention to destroy that prior adverse right, ${ }^{26}$ whether that intention is formed before or after registration. ${ }^{27}$ Specifically: ${ }^{28}$

If the defendant acquired the title intending to carry out the agreement with the plaintiff, there was no fraud then; the fraud is in now repudiating the agreement, and in endeavouring to make use of the position he has obtained to deprive the plaintiff of his rights under the agreement. If the defendant acquired his registered title with a view to depriving the plaintiff of those rights, then the fraud was in acquiring the registered title. Whichever view is accepted, he must be held to hold the land subject to the plaintiff's rights under the agreement.... .

In Locher v. Howlett, it was said that it was the settled construction of the section that the purchaser is not affected by knowledge merely of the existence of a trust or unregistered interest but is affected by knowledge that the trust is being broken or that the owner of the unregistered interest is being deprived improperly by the transfer under which the purchaser is taking. ${ }^{29}$ Some judges have gone even further and asserted that fraud is not limited to cases of actual knowledge but that the test is whether the purchaser knows enough to make it his duty as an honest man to make further enquiries. ${ }^{30}$

Equitable fraud, then, is far from dead in New Zealand's Torrens system; but there has been one decision in which a somewhat different attitude was taken. In Ruapekapeka Sawmill Co. Ltd. v. Yeatts and Another, Haslam J. said that the literal text of the section seemed "to obviate the necessity of considering any question of notice." $31 \mathrm{He}$ did not, however, give a definite decision to that effect and went on to consider what the result would be if the doctrine of notice was relevant. Also, in a second case, Harris v. Fitzmaurice (Gruar, Third Party) ${ }^{32}$ the fact that a transferee had been told that there was a weekly tenant in occupation of the property being transferred was held not to subject him to the formal lease actually in existence but of which he had not been told. However, this decision is perhaps less significant since there is no real conflict between it and the decision in Merrie v. McKay ${ }^{33}$ which was distinguished. Essentially the decision was that the transferee had not had notice of the interest which as registered proprietor he now sought to defeat.

24 Supra, n. 19 at 265.

2: Finnoran v. Weir (1887) 5 N.Z.L.R. 280; Locher v. Howlett (1894) 13 N.Z.L.R. 584; Merrie v. McKay (1897) 16 N.Z.L.R. 124; Webb v. Hooper [1953] N.Z.L.R. 111.

4" Finhoran v. Weir (1887) 5 N.Z.L.R. 280.

2i Merrie v. McKay (1897) 16 N.Z.L.R. 124; Webb v. Houper [1953] N.Z.L.R. 111.

2* Merrie v. McKay, id. at 127-128, per Prendergast C. J.

$2 y$ (1894) 13 N.Z.L.R. 584 at 595-596.

st Id. at 597-598. Waimiha Sawmilling Cu. v. Waione Timber Co. [1923] N.Z.L.R. 1137 at 1151 per Stout C.J., and at 1175 per Salmond $J$..

" [1958] N.Z.L.R. 265 at 271.

.14 [1956] N.Z.LR. 975.

is Supra, n. 25. 
The decision in Merrie v. McKay is of interest as it was relied on in the fairly recent case of Webb v. Hooper ${ }^{34}$ where the basic New Zealand approach was reasserted. The facts in Merrie v. McKay were that the plaintiff had entered upon land and erected some buildings on it under an agreement with the registered proprietor at the time for a ten year lease. The agreement also provided that the lessor was to take the buildings at a valuation at the end of the lease and the plaintiff was to have the option of purchasing should the lessor desire to sell. The defendant was the third person into whose hands title to the land had passed since the agreement was entered into. Each purchaser had taken with knowledge of the plaintiff's rights under the agreement and of his possession and expenditure upon buildings. The agreement had never been registered. The dispute arose because the defendant sought to deny the plaintiff's "rights" by virtue of his clean registration as proprietor. The court held that the plaintiff had lost his option to purchase by failing to exercise it when the occasion for it arose on the original sale by his lessor. However, the court said that it would not allow the defendant to deny him his other rights as such denial would be fraudulent. Fraud then consisted of selling to defeat an unregistered interest of which the registered proprietor had notice prior to his registration.

Of particular significance is the statement quoted earlier ${ }^{35}$ which was also quoted with approval and relied on in Webb v. Hooper. In that case the purchaser of land had taken with notice of an unregistered right to keep a shed upon the land together with the right to pass to and from it and to take it away if desired. Precisely at what point of time notice was acquired remained uncertain, but the court held that it did not matter anyway provided that the notice was acquired prior to registration. Here again it was the conjunction of knowledge of the interest with the intention to defeat the interest that constituted fraud.

Most of the decisions so far discussed were delivered by single judges. The problem of interpreting and applying the section was, however, taken on appeal from New Zealand to the Judicial Committee of the Privy Council in Waimiha Sawmilling Co. v. Waione Timber Co. ${ }^{36}$ The Privy Council affirmed that the word "fraud" as used in the section means some positive act of dishonesty and not constructive or equitable fraud. The Committee then said: ${ }^{37}$

If the designed object of a transfer be to cheat a man of a known existing right, that is fraudulent and so also fraud may be established by a deliberate and dis. honest trick causing an interest not to be registered and thus fraudulently keeping the register clear. It is not, however, necessary or wise to give abstract illustrations of what may constitute fraud in hypothetical conditions, for each case must depend upon its own circumstances. The act must be dishonest, and dishonesty must not be assumed solely by reason of knowledge of an unregistered interest.

That statement in itself and the decision generally could be interpreted as supporting either the Australian or the New Zealand approach. It has been taken by some authorities to support the New Zealand

\footnotetext{
is. Id.

${ }^{35}$ Supra, at 110, n. 28.

* Supra, n. 10. Appeals to the Privy Council from Canada have, of course, been abolished. However, Waimiha Saumilling Co. v. Waune Timber Co. was decided well prior to the abolition of such appeals and has been accepted into Canadian law for whatever it decides. Its equivocality enables it to be used by supporters and opponents of the literal application of the section.

$\therefore$ Supra, n. 10.
} 
approach. ${ }^{38}$ Put simply, the prevailing view seems to be that if a transferee takes with knowledge of an interest which will be defeated by his registration, his "designed object" is "to cheat a man of a known existing right."

In his examination of the Real Property Act of New South Wales, Mr. J. Baalman comments ${ }^{39}$ that, whether or not Dr. Kerr's observation $^{40}$ that the net result of the dicta in the Waimiha Sawmilling case and Loke Yew v. Port Swettenham Rubber Co. ${ }^{41}$ supported the New Zealand attitude was accurate at the time it was made, it must be reconsidered in the light of Abigail v. Lapin. ${ }^{42} \mathrm{He}$ contends that the latter judgment supports the Australian line of cases. He says this because in the Abigail case the Privy Council placed stress on the failure of the equitable interest holders to protect their rights by means of the caveat machinery provided by the legislation. In other words he argues that the emphasis should, in the light of that case, be placed on asking whether the opportunity to protect by means of a caveat was employed or neglected rather than on whether there was an intention to become registered with knowledge of and so as to deprive another of his outstanding equitable interest.

The Judicial Committee's opinion in the Abigail case does not, however, support this view. The Committee did mention the failure to make use of the caveat provisions and did quote with approval from Griffith C. J.'s judgment in Butler v. Fairclough ${ }^{43}$ in which he emphasized such failure as being a major factor leading to postponement of a prior interest to a later-perhaps even sufficient of itself. The Committee also referred to Lord Selborne's statement in Agra Bank v. Barry ${ }^{44}$ in which he pointed out that the so-called duty of a purchaser to investigate title is not a duty which he owes to a possible holder of a latent security but a prudent course in his own interest. (Lord Selborne commented upon the policy of the Irish Register Act which provided that a prior unregistered deed is fraudulent as against a later registered deed. His Lordship said "that it would be altogether inconsistent with that policy to hold that a purchaser or mortgagee is under an obligation to make any enquiries with a view to the discovery of unregistered interests" 45 ). But the crucial words uttered by the Privy Council in the Abigail case, so far as Mr. Baalman's contention is concerned, were that it is "unnecessary to add that when such questions need be considered, it is always understood that the purchaser or mortgagee has not either express or constructive notice of the prior charge." 46 Indeed, Lord Selborne himself had said that it was quite consistent with the policy of the Irish Register Act to estop a purchaser from contending that prior unregistered interests are void

\footnotetext{
38 Stanton J. in Webb v. Hooper, supra, 25 at 114; Kerr, The Principles of the Australian Land Titles (Torrens) System, at 216.

sy Baalman, Commentary on the Torrens System in New South Wales, at 167.

I0 Id.

$"$ [1913] A.C. 491.

12 [1934] A.C. 491.

is (1917) 23 C.L.R. 78.

"1 (1874) L.R. 7 H.L. 135.

t.s Id. at 157.

16 Supra, n. 42 at 506.
} 
merely because unregistered when he actually knows of their existence when he takes his deed. ${ }^{47}$

The New Zealand and Australian cases previously referred to were cases in which there was express or constructive notice. Butler v. Fairclough and Abigail v. Lapin were different because there was no question of notice involved. However, it will be argued later in this paper that the caveat machinery is, or should be, of some importance to this question, even where there is notice.

A somewhat similar approach can be detected in decisions handed down by courts in Alberta, British Columbia and Manitoba. It is, perhaps, possible to explain some of the decisions in which the protection of the section has been denied registered proprietors as having been given in cases of actual fraud as was done in the Saskatchewan case of Hackworth v. Baker. ${ }^{48}$ For example, in Sydie v. Saskatchewan and Battle River Land and Development Co. ${ }^{49}$ the registered proprietor had taken advantage of a mistake made by the plaintiff and in so doing was patently abusing the relationship which existed between himself and the plaintiff. He had after all been entrusted with the obtaining of the land concerned for the plaintiff.

However, not all of the decisions can be so easily explained. There are a number of decisions in which full effect appears to have been denied to the section and some in which it seems no argument was addressed to the court on the section. In a comment on Zbryski v. City of Calgary" in this journal, it was asserted that the section "has been argued in very few Alberta cases and has not been given its full literal effect by any Alberta Court."51

An example of the reasoning adopted in Alberta is found in Stephens v. Bannan and Gray. ${ }^{52}$ There the majority appeared willing to hold that notice of a prior interest when coupled with intent to defeat or prejudice that prior interest amounted to fraud. However, their Lordships did concede that notice received after acquisition of the adverse interest did not render fraudulent subsequent steps properly taken to make the adverse interest safe. But except in cases where the getting in of the legal estate involves a breach of trust the tabula in naufragio doctrine has that result without need to resort to the notice section in any event. The decision is an old one, predating Hackworth v. Baker 3 by many years. It may be said that it would no longer be followed in light of more recent decisions noted earlier. ${ }^{54}$ However, Zbryski v. City of Calgary raises some doubt about this. It may be that the latter

\footnotetext{
4: (1874) L.R. 7 H.L. 135 at 157.

is Supra. n. 12 at $337-340$.

19 (1913) 5 W.W.R. 194.

iv (1965) 51 D.L.R. (2d) 54.

it Supra, n. 11 .

iz (1913) 5 W.W.R. 201. In this case Beck J., speaking for the majority, noted that it had been held in Sydie v. Saskatchewan and Ballle River Land and Development Co. that notice of a prior interest together with knowledge that the acquisition of an adverse interest would defeat or prejudice the prior interest plus the acquiring of the adverse interest is fraud. It is pointed out above that the Sydic case can be explained and justified without recourse to such a wide principle. However, the court in Stephens v. Bannan and Gray appeared to approve of the principle.

Beck J. also stated that in Sydic it had been said that this view was in accordance with decisions of the Australian colonies. That this was not so is evident from the Australian cases cited earlier. The statement appears in fact to have been based upon an opinion expressed in Hogg's Australian Torrens System at 835 et seq.

is Supra, n. 12.

is Supra, n. 12.
} 
decision can be justified even in the face of the section on the grounds that the City of Calgary misleadingly induced the plaintiff to refrain from safequarding his right.55 There remains, however, the disturbing fact that the section was not even adverted to in the judgment. Perhaps it was not argued but its relevance to the judgment, if full effect was to be given it, seems obvious.

The same approach as exhibited in Stephens v. Banning and Gray has from time to time been adopted in the other provinces of Western Canada, apart from Saskatchewan. In Beaver Lumber Co. Ltd. v. Pritchard $^{56}$ the Manitoba King's Bench said that the plaintiff company, knowing that the defendant had an unregistered transfer "... went behind his back", obtained a transfer to itself and became registered fraudulently. The only element required in addition to notice was the intention to deprive another of his "just" rights.

In Ukrainian Greek Orthodox Church v. Independent Bnay Abraham Sick Benefit Free Loan Association and Riverside Cemetery the Manitoba Court of Appeal said that if the president of the defendant company had had knowledge that others "owned" the land but had continued with the transaction to become proprietor he would have been guilty of "something approaching fraud." 57 What the consequences of that would have been their Lordships did not say. It is not clear whether or not they would have drawn a distinction between fraud and "something approaching fraud." The more reasonable inference seems to be that they would have been prepared to overthrow a registration so obtained.

In an early British Columbia case, Hudson's Bay Co. v. Kearns and Rowling, Davie.C.J., on appeal, was fully prepared to hold against an intending purchaser who "after express notice of an unregistered interest enters upon and proceeds with his purchase."58 Then in Greveling v. Greveling and Blackburn, O'Halloran J.A., in a dissenting judgment, noted that the British Columbia section contained

ss $C f$. the comment referred to in n. 51, supra.

s6 [1933] 3. W.W.R. 35.

s7 (1959) 29 W.W.R. 97 at 107; 20 D.L.R (2d) 363 at 371 . The facts in this case were that the Riverside Cemetery, the registered owriers of the land, entered into an agreement to sell a plot of land to the plaintiffs, Ukrainian Greek Orthodox Church, and then discovered that the land had been previously been sold to the defendant Association. This transaction had not yet been pursued io completion by registration. The registered owners immediately informed the plaintiff of the situation and returned the purchase money. The latter refused to resile from the contract and lodged a caveat to protect its position. It then sought specific performance of the contract. It should be noted that in this case the later acquired interest was still unregistered and therefore could not claim the protection of the notice section which is interpreted as applying only to registered properties. Davies v. Ryan [1951] V.L.R. 283; Templeton v. Leviathan Property Ltd. (1921) 30 C.L.R. 34 at 54; Butler v. Fairclough (1917) 23 C.L.R. 78 at 91; Thom's Canadian Torrens System 197, 228 (2d ed. Di Castri).

The muddle arose because shortly after the then President of the Riverside Cemetery Company had acquired control of the company, a fire destroyed the records of the company and the registration in the name of the Riverside Cemetery in the Land Titles Office had not been altered. In 1921, when the defen. dant Association had bought the land, it had lodged a caveat against the land but that caveat had been omitted when a fresh certificate of title was issued in 1957. In fact, the Association had received from the Riverside Cemetery a certificate of ownership under the Cemeteries Act S.M. 1937.1938, c.4. On the basis of that certificate, the Association filed a caveat on November 9, 1957. However, the officials of the Land Titles Office had rejected the caveat because they considered the description of the land unacceptable.

That caveat was rejected as an exhibit at the trial hearing but was held on appeal to have been improperly so treated. Priority amongst caveators was governed, according to 8. 148 (1), Real Property Act, R.S.M. 1954, c. 220 , by time of filing. Thus, notwithstanding the "wrongful" rejection of the caveat, it had priority over the caveat filed by the plaintiff church four days earlier.

Adamson, C.J.M. then went on to consider what he referred to as "substantial grounds" for rejecting the plaintiff's claim for specific performance. While discussing the question of factual mistake and the effect that had upon transactions under the Real Property Act, His Lordship made the remark referred to in the text. See also Ruthenian Greek Catholic Church v. Fedsyk [1922] 3 W.W.R. 872.

sn (1896) 4 B.C.R. 536 at 551. 
neither the words "except in case of fraud" nor words to the effect that knowledge of an unregistered interest shall not of itself be imputed as fraud. He held that a purchaser would, notwithstanding the section, be affected by notice express or implied. Furthermore, he asserted that even if a purchaser did not have notice prior to purchase, his position, if he received it prior to completion, would be no better than if he had received it at the outset.59 This decision has been commented on disapprovingly. It is criticized, for example, by $\mathrm{Mr}$. Di Castri in the second edition of Thom's Canadian Torrens System. ${ }^{60}$ The terms of his criticism are that it is implicit in the Act and in the decided cases that the section purports to abolish the doctrine of notice, including, in the absence of fraud, the case of knowledge of an unregistered instrument. The problem is that many of the decided cases reveal a willingness to find fraud where nothing more than knowledge and intention to defeat can be shown.

O'Halloran J.A. was, in Greveling v. Greveling and Blackburn, delivering a dissenting judgment in respect of the position of the registered proprietor. But even the majority judgment delivered by Robertson J. A. appeared to accept decisions such as Hudson's Bay v. Kearns and Rowling as establishing that a purchaser who completes his purchase with knowledge that his vendor is not an unencumbered owner in equity is guilty of actual fraud.61 $\mathrm{He}$ differed from O'Halloran J.A. in that he found there was not the requisite knowledge to establish fraud on the part of the transferee in that case. The British Columbia section does not expressly deny that knowledge of a trust or unregistered interest is to be imputed as fraud and that may possibly justify the view that O'Halloran J.A. took of its effect. However, it does not seem logical to say that a section which states that no person taking a transfer from a registered owner shall be affected by notice, express, implied or constructive, actually means that a transferee shall be so affected and thereby held to have committed equitable fraud.

Most of the cases which have been treated as examples of failure to give the section its full effect are not particularly recent. However, it is submitted that a sufficient number of them have been decided in the last twenty years to raise a reasonable doubt as to the future application of the section in some jurisdictions. Furthermore, the fact that each case must depend upon its own circumstances leaves to the courts a very wide area of discretion and makes it difficult to say that any decision by no matter how superior a court settles the boundaries of fraud. It is not denied that some area of discretion is desirable in order to deal satisfactorily with the commission of frauds. It is submitted, however, that many of the cases examined show that the discretion has been and in some cases still is being used with the result that actions which it was intended should not constitute fraud are being held to amount to fraud.

If one asks the question whether a registered proprietor is completely freed from the effect of notice when legislation not only prescribes that registration is essential for the passing of an interest but also that persons dealing with the registered proprietor shall not be

\footnotetext{
ity [1950] 1 W.W.R. 574 at 596-597.

iiv Thom, Canadian Torrens System 241 (2d ed. Di Castri).

s) Id. at 608. Compare Re Pacific United Developers (1962) Ltd. (1965) 51 D.L.R. (2d) 93.
} 
affected by notice, direct or constructive, of trusts or unregistered interests, the answer "yes" appears to be compelled. Yet in Alberta, British Columbia, Manitoba and New Zealand the courts have on a number of occasions answered in the negative. How can this be so? The solution must be in the exception in case of fraud, even in British Columbia, where it is not express. ${ }^{62}$ Notice shall not of itself be imputed as fraud but when coupled with some other factors it may still be a constituent element of fraud. It is instructive, therefore, to look at the cases to determine what factors may be taken to supply the necessary additional element.

Factors such as the following have been referred to by a number of judges: a confidential relationship between the claimant and the registered transferee; a voluntary transfer to the transferee executed by mistake; a transfer with limitations imposed by the transferor; taking advantage of a mistake made by the claimant in dealing with the registered proprietor; and resorting to a deliberate dishonest trick to prevent the claimant from registering his interest. ${ }^{63}$ In Hackworth v. Baker, Turgeon J.A. illustrated this by reference to decided cases. ${ }^{64}$ But what were the additional factors found in some of the other cases? Knowledge that the prior right will be destroyed, ${ }^{65}$ or that the prior interest holder will be deprived "improperly" by registration of the later acquired interest; ${ }^{6}$ intention to destroy or prejudice the prior interest ${ }^{67}$ even if the intention was formed after registration. ${ }^{68}$

These cases raise difficult problems. If intention to destroy or prejudice a prior interest is sufficient to constitute registration with notice fraudulent, if mere knowledge that destruction or prejudice will follow upon registration is sufficient, how will there ever arise a case in which the section will operate to protect a transferee from the effect of notice? Knowledge or, at least, expectation that destruction or prejudice will follow upon registration is going to be present in every case in which conflict arises between a registered proprietor and the claimant to a prior unregistered "interest". Intention to destroy or prejudice is going to be present in every case, though the intention may well be formed after registration. Such an interpretation reduces the section to impotence, except where the transferee has "but a mere hint of some possible irregularity" whereupon the section may absolve him from carrying enquiries into the possible irregularity any further. One can hardly regard so limited an interpretation as doing justice to the words of the section, whether it is read on its own, or, as it should be, in conjunction with the rest of the Act. It is submitted that, where nothing more can be shown against a transferee than knowledge that a prior unregistered interest would be defeated or an intention to defeat such an interest by exercising legal rights given him by the Act, the section is not being correctly applied if fraud is found.

62 Even in British Columbia, where the section does not contain an express exception in case of fraud, it is clear from the general tenor of the Act that fraud would be an exception. (8. 38(I)(i)).

os Hackworth v. Baker, supra, n. 12 per Turgeon J. A. at 339, per Martin J. A. at 355; Waimiha Sawmilling Co. v. Waione Timber Co., supra, n. 10 at 106-107.

ot Supra, n. 12 at 337.339 .

6.5 Supra, n. 25.

66 Supra, n. 29; Hudson's Bay Co. v. Kearns and Rowling, supra, n. 58.

${ }^{67}$ Supra, n. 26; Stephens v. Bannan and Gray, supra, n. 52.

ss Supra, n. 28. 
What the New Zealand courts have done is place emphasis on the presence or absence of fraud; only if fraud is absent is protection against notice obtained. They have been much concerned to see that nothing even faintly resembling fraud or sharp practice should be permitted and have thus been more willing to retain some part of the concept of equitable fraud. The courts in Alberta, British Columbia and Manitoba appear to have adopted a similar approach. On the other hand, the Australian courts have placed the emphasis on protection against notice. Protection against notice is obtained unless fraud is shown and it is not shown merely by the fact of notice. This difference in emphasis or direction of approach has produced markedly different results from application of essentially the same statutory provisions.

Perhaps Richmond J. in the National Bank case expressed most clearly the thought which underlies the New Zealand attitude: ${ }^{69}$

In many instances the rule of equity that notice is fraud, must be recognized as consentaneous with the principles of common morality; for it may be an act of downright dishonesty knowingly to accept from the registered owner a transfer of property which he has no right to dispose of.

It is said that it is contrary to the principles of common morality improperly to deprive someone of an interest, or at least improperly to deprive him in a situation in which it is known, or perhaps merely strongly suspected, that he will not be adequately compensated. This is a proposition against which it is hard to argue. Yet Australian judges, and judges in other jurisdictions where Torrens type legislation applies, have been quite prepared to uphold transactions by which unregistered interest holders have been deprived of their interests even though the purchasers in those cases have been aware of the outstanding interests and of their certain or likely destruction.

Is it simply the case that different standards of morality exist in these different jurisdictions? It is suggested that this is not the answer. A countervailing factor has been referred to in several of the Australian and Canadian cases. That factor is the existence of machinery whereby holders of unregistered interests may protect their interests-the caveat system.

In the New South Wales case, Cooke v. The Union Bank, Manning J. said that everything material to title should appear on the certificate or from search at the Registrar-General's office. ${ }^{70}$ In Oertel v. Hordern, A. H. Simpson C.J. in Equity pointed out that the person suffering from his decision in favour of the registered transferee could have and should have lodged a caveat "which would have effectually preserved his rights." 71

The reasoning behind the Australian and Saskatchewan decisions is that the Legislature has set out to eradicate the equitable doctrine of notice from conveyancing of Torrens Title land; but in doing so has not left the unregistered interest holder without protection. If he fails to avail himself of that protection by lodging a caveat it is intended that purchasers shall be able to go ahead and register so as to defeat his interest even with notice of that interest. The Torrens

".' Supra, n. 19 at $263 \cdot 264$.

i" Supra, n. 12.

$\therefore$ Supra, n. 12. 
system is intended to provide certainty of title and to facilitate dealings with interests in land.72

Perhaps this view of the Torrens scheme is best summed up in the words of Turgeon J.A. of the Saskatchewan Court of Appeal in Hackworth v. Baker. ${ }^{73}$ In that case the Court of Appeal held that the fact that a transferee of land who registers with knowledge of an outstanding unregistered transfer of the same land may, in addition to wanting to acquire the land, also wish to get rid of an undesirable neighbour who is in occupation of the land did not amount to fraud within the meaning of s.216 of the Saskatchewan Land Titles Act of 1930. This section, now replaced, corresponded almost exactly with the section under discussion.

Turgeon J.A. who delivered the majority judgment summed up his view of the essence of Torrens system in the following comment upon the indefeasibility sections: ${ }^{74}$

These provisions are all essential features of our land title system; it is the right of registered owners and of those who deal with registered owners to invoke their protection; and it is incumbent upon those who claim equities, or who retain in their own possession instruments such as transfers, which might be registered, and which can pass no interest until they are registered, to bear them in mind. It is the intention of the statute that notice of rights and interests shall be given through the land titles office. This notice may be given by the registering of the instruments, the filing of a caveat, etc., according to the nature of the case. Otherwise the person claiming the right or interest is running the risk of seeing his claim extinguished even by the act of someone having notice of it.

This decision has been approved and applied on a number of occasions since, ${ }^{75}$ and in Clark v. Barrick the necessity of filing a caveat to protect an interest in land covered by an unregistrable instrument was clearly laid down. ${ }^{76}$ But there have been dissents from this view. In T. M. Ball Lumber Co. v. Zirtz, the dissentient McNiven J.A. laid stress on the words "of itself" in the last lines of the section and found in the facts something additional to mere knowledge of the unregistered transfer. ${ }^{77}$ In C.P.R. v. Turta, Rinfret C.J.C. expressed the view that acceptance of the wider view of the immunity from notice given by the section would lead to an "intolerable situation" and "would do away with all traditional principles of law and equity". Even then he said that he was not sure that the section did not "boast of such intention."78

The interpretation placed upon the section by the Australian courts and the majority in the Saskatchewan Court of Appeal appears more consistent with the words used in the section than does that espoused by the New Zealand courts and the courts of the other provinces of Western Canada. Certainly it is more consistent than the reasoning adopted by Richmond J. in Locher v. Howlett ${ }^{79}$ and Salmond J. in Waimiha Sawmilling Co. v. Waione Timber Co. ${ }^{80}$ Both judges said

\footnotetext{
12 Note Prof. W. N. Harrison's strictures against approaching the Torrens statutes with preconceived notions as to what they were intended to achieve in (1952.55) 2 University of Queensland Law Journal 206, and Mr. J. Baalman's reply in (1956-1958) 2 Sydney Law Review 87.

73 Supra, n. 12.

II Id. at 333.

is Supra, n. 12.

76 [1949] 2 W.W.R. 1009 at 1023 et seq., [1950] 1 D.L.R. 260 at 273 et seq.

7 Supra, n. 75.

78 [1954] 3 D.L.R. 1 at 3.

70 Supra, n. 25 at 597.698.

co Supra, n. 30 at 1175.
} 
that absence of actual knowledge was not enough and that a duty rested upon a purchaser who strongly suspected that a third party was being deprived by his transaction to make full enquiries before proceeding. Their Lordships spoke of the defrauding of third parties but made it fairly clear that that was established by showing purchase and registration with knowledge that a third party had an interest which would be defeated without compensation being paid.

Though the Australian and Saskatchewan interpretation is more consistent with the language of the section, it nevertheless raises difficulties. Turgeon J.A. said it was the intention of the Legislature that notice should be given through the land titles office. ${ }^{81} \mathrm{~A}$. H. Simpson C.J. in Equity in New South Wales, spoke of the duty to caveat in order to protect unregistered interests. ${ }^{82}$ While it is certainly possible to argue that it was the intention of the Legislature that interests should be protected either by registration or lodging of caveats, it is a matter of some doubt as to whether any of the various Acts clearly places a duty upon interest holders to take such action. If the so-called duty of a purchaser to investigate title is really a prudent course of action on his own behalf, ${ }^{83}$ the same could be said of the "duty" to caveat to which A. H. Simpson C.J. referred. If the holder of an interest can in some other way inform purchasers of his interest should he suffer because he does not also lodge a caveat?

The question is not a new one. It greatly exercised the minds of the Commissioners appointed to inquire into the law of real property in the United Kingdom in the nineteenth century. Their second report, tabled in 1830, together with appendices, contains arguments both for and against eliminating the doctrine of notice from a general registry system. ${ }^{83}$ Prior to that date statutes had been enacted which appeared to be designed to operate independently of notice and certain judges such as Lord Hardwicke ${ }^{84}$ and Lord Alvanley ${ }^{85}$ had expressed criticism of the fact that on occasions the courts had allowed the doctrine of notice to break into the strictness of the statutory rules. It should be noted, however, that the latter criticisms were directed more against allowing in doubtful parol evidence to establish notice rather than against the continued application of the doctrine of notice at all. Their Lordships would seemingly have not objected to applying the doctrine in clear cases of notice.

Be that as it may, it is plain that the doctrine of notice was under attack and that the attack was directed at the giving of effect to actual notice as well as constructive notice. ${ }^{86}$ Although it was with respect to the latter that most problems arose, the difficulty of separating the two by definition was considered insuperable. What could be considered so objectionable about the operation of the doctrine of notice? Is it not really fraudulent of someone to seek to defeat a prior interest of which he had knowledge when he obtained his interest? One objection referred to earlier was that notice was often difficult to prove or disprove and this led to attempts to fabricate

\footnotetext{
st Hackworth v. Baker, supra, n. 12.

32 Oertel v. Hordern, supra, n. 12.

as Second Report of the Commission on Real Property, 1830 (575), xi.

ot Hine v. Dodd (1741) 2 Atk. 275, 26 E.R. 569.

w Jolland v. Stainbridge (1797) 3 Ves. 478, 30 E.R. 1114; Wyatt v. Barwell (1815) 19 Ves. 435, 34 E.R. 578.

* Second Report at 34-35.
} 
proof usually in a parol form. But could not that sort of situation be left to the judges to deal with? The Commissioners thought not as there was no way of telling what any particular judge would regard as sufficient or insufficient proof. That would lead to uncertainty, which they argued, was undesirable in relation to title to land and its transfer. ${ }^{87}$

What other objections to the doctrine of notice were there? One, stemming again from the desirability of certainty and security of title, its acquisition and its transfer, was that the operation of the doctrine permits and even encourages persons claiming interests in land to refrain from registering their interests or claimed interests. This must detract greatly from the value of a system of registered title in which the register is to be "everything".88 The Commissioners in 1830 were very much impressed by the ease and frequency of the creation of false titles by suppression of documents and through accident, inadvertence and ignorance. ${ }^{89}$ They concluded that the register system they were proposing should operate independently of notice, ${ }^{90}$ and that even where it could be proved that the registered purchaser had received notice of a prior unregistered interest this should not be allowed to affect his title. ${ }^{91}$

Their reasoning started from their conclusion that the public good required that all interests should be properly placed on the register. ${ }^{92}$ It followed, then, that in order to obtain protection a purchaser should have to comply with a form (i.e. register his interest) and that form should be made simple and easy. Then a purchaser who omitted the form or formality would have no just ground of complaint if a later interest taker did comply with the form and protection was not afforded the first purchaser. Even if his omission was not wilful, it would, unless it had been induced by the later interest taker, be attributable to his own or his agent's want of care.

The Commissioners supported their views by reference to the Statute of Frauds requirements which had, in their opinion, no more drastic an effect than would the absolute requirement of registration or the elimination of the doctrine of notice. It was asserted that the public good occasioned by the Statute of Frauds requirements far outweighed the sacrifice of a few individual interests. Bentham's influence appears to have been felt strongly by the Commissioners. They did acknowledge that some equitable exceptions to the Statute of Frauds on grounds of moral justice and compassion had been allowed but asserted that they were generally considered unwise. They pointed also to the Code Napoleon ${ }^{93}$ in which the doctrine of notice had been eliminated from the registry system on the grounds that to do other-

\footnotetext{
i Id. at 38.

an Fils v. Kinutules (1906) 26 N.Z.L.R. 604.

ny Second Keport at 3.

Id. at 35 .

y) $l$ d. at 36 .

92 'The Comissioners' concept of the public good is interesting because though they were in favour in general principle of the register being unrestrictedly open for public inspection they did not regard this as essential and they were prepared to see access restricted to those who could show some interest in the land the title to which they wished to search.

Their view was that it was for the public good that civil rights should be ascertained without difficulty. In order to achieve this end, it was essential that the law upon which those civil rights depended should, as far as possible, be general in operation and not varying according to circumstance (Second Report at 38).

s.t s. 3, tit. 2, c. 6, art 1071 .
} 
wise would be to negate the system. Reference was also made to the Scottish law which was said to be similar in this regard.94 The recommendation, then, was for the establishment of a general registry system which would give protection from, inter alia, the effect of notice whether actual or constructive.

What of the complaints that such a law encourages fraudulent behaviour by purchasers and that it enables fraudulent vendors to sell the same land twice provided that the first purchaser has not registered at the time of the second sale and the second purchaser, being aware of this, acts with appropriate haste to obtain for his interest the benefit of registration? Can the race to the register be condoned? The Commissioners were presented with submissions on these questions by experienced barristers and solicitors but their eventual conclusion was, nevertheless, as just stated. They did not think that the elimination of the doctrine of notice would exclude equity jurisdiction in cases of actual fraud. This was because "in all cases in which priority may be given to a registered over an unregistered deed by means of fraud, there will usually be other circumstances by which, independently of notice, a fraudulent intention will be manifested." Their examples of what would constitute fraudulent conduct correspond closely with those given by various courts and referred to earlier. ${ }^{95}$ The Commissioners instanced conspiracy and improper conduct preventing or impeding the registering of one deed in order to give effect to another and also said that fraud might be shown by inadequacy of price or the circumstances under which the subsequent deed was executed.96 Here an element of doubt creeps in. Would circumstances such as where B takes a transfer from $V$ and registers it knowing that $A$ earlier took a transfer of the same property from $V$ but has not yet registered it show fraud according to the tests laid down by the Commissioners? Seemingly they would not because the Commissioners did advert to the possibility of a vendor or mortgagor with fraudulent intention seeking to take advantage of his purchaser's mortgagee's failure to register by effecting a subsequent sale or mortgage. They concluded that to allow the doctrine of notice to give protection against such happenings would be to unnecessarily detract from the security of every purchaser just to give a few purchasers a chance to protect themselves against "the effects of their own misfortune or carelessness."97

They proposed to offer a purchaser protection by allowing him to caveat temporarily; thus giving him time to obtain the full protection of registration. This latter process was to be simple and inexpensive in order to make the protection available in reality, not merely in theory. If he omitted to take advantage of that protection he was instead relying on confidence in the parties and could not justly complain if another person, properly relying on the system, defeated his interest. These proposals were not dreamed up but were formulated after taking evidence from a large number of practitioners. Nevertheless, they

\footnotetext{
94 Second Report at 39.

9s Supra, at 108, 116.

Socond Report at 39.

yi Id. at 40. They did, however, propose a system of in personam remedies by way of actions for damages against the appropriate parties where the later "indefeasible" interest had been taken with actual notice of a prior unregistered interest. This, they felt would be fair and would deter conduct of doubtful propriety, while not disturbing the security of title afforded by the system (Second Report at 41, 42).
} 
were propounded over a century ago. It is necessary to consider whether the experience of a century of the operation of a system similar in outline to that proposed by the Commissioners has rendered any of their basic precepts untenable. Numerous articles have been written which contain valuable evidence on this matter. ${ }^{98}$

As a preliminary comment it should be noted that it is open to doubt how far the Torrens legislation of the jurisdictions being looked at does, as presently interpreted, achieve the aim of security of title. In Canada, C.P.R. v. Turta has been criticised as having "scuttled the aim of security of title" in favour of the aim of facility of transfer. ${ }^{99}$ Also the Privy Council decision in Frazer v. Walker has been similarly criticized for achieving the same result in Australia and New Zealand.100 The substance of those decisions and criticisms will not here be entered into. The matter is of obvious importance to the future of the Torrens system but the question under discussion appears susceptible of independent treatment. However, the general effect must be noted as the arguments in favour of the elimination of the doctrine of notice are substantially based upon the desirability of achieving security of title.

Probably of more importance is the fact that, quite apart from the effect of the doctrine of notice, it is readily apparent that the register is by no means everything. As a conclusive and exclusive record and guarantee of title it suffers both from anomalies within its own confines and from the enactment from time to time of inconsistent statutes. A powerful exposition of the effect of such factors on the operation of the Torrens system in New Zealand is to be found in an essay by Professor G. W. Hinde of Auckland. ${ }^{101} \mathrm{He}$ indicates just how drastic have been the incursions made by New Zealand statutes which have created interests which stand or may stand outside the Torrens system and yet prevail over interests registered under it. ${ }^{102} \mathrm{He}$ also analyses defects arising from the legislation itself and some suggestions for its improvement. ${ }^{103}$ The same deficiencies appear to exist, to a greater or lesser degree, in Canada and Australia. The argument that seems to flow from this is that because the ideal is already unattainable it does no great harm to allow the doctrine of notice, albeit in a modified form, to further detract from security of title in the interests of morality and fairness.

Certainly the Torrens system is far from perfect. However, many if not all of the imperfections can be and should be dealt with by the responsible legislatures. As Professor Head points out, notwithstanding the severe defects of the system, even some of those who have lost heavily through its operation have thought it preferable to any other

\footnotetext{
9* Head, The Torrens System in Alberta, A Dream in Operation, (1957) 35 Can. Bar Rev. 1; Hinde, The Future of the Torrens System in New Zealand, The A.G. Davis Essays in Law. 77 (ed. Northey); Wills, Just How Indefeasible Is Your Land Transfer Title?, [1963] N.Z.L.J. 269; Harrison, Indefeasibility of Torrens Title, (1956) 2 University of Queensland Law Journal 206; Watts, Protection Against Notice Under the (N.S.W.) Real Property Act, 1900. (1932) 6 Aust. L. J. 85; Adams, The Torrens System, The Insecurity of Purchasers Under the Transfer of Land Act, I893, (1948) 1 U.W. Aust. Ann. L. R. 11.

99 Head, supra, n. 98 at 19. Ruoff, Torrens Titles to Minerals in Alberta, (1959) 35 Can. Bar Rev. 308; Ruoff, An Englishman Looks at the Turrens System 66-82.

two Hinde, Case Note, (1967) 2 N.Z.U.L.R. 458 at 467; Tomm, Mr. Bumble Right Again, [1967] N.Z.L.J. 129.

Iu' Hinde, supra, n. 98.

ive /d. at 79.98. A striking example of this is afforded by Miller v. Minister of Mines [1963] 2 W.L.R. 92.

sul Id. at 98-129.
} 
system so far devised. ${ }^{104}$ Professor Hinde also commented upon the high degree of public confidence enjoyed by the system in New Zealand. ${ }^{105}$ The writer cannot accept the viewpoint which would allow inroads to be made unnecessarily into the security afforded by the system simply because defects already exist. To the extent to which the efficacy of the system depends upon notification of interests upon the register, and to the extent to which that is possible, it should be insisted upon. It is submitted that the Acts demand, in the sections dealing with passing of interests, conclusivity of registered title and immunity from notice. Furthermore, the caveat provisions do appear to be designed as an attempt to provide protection against the fact that it is generally not possible to effect registration immediately upon the acquisition of an interest.

That Canadian and Australian courts have adverted to this combination of features of the Act was noted before. ${ }^{106}$ It was conceded then that the caveat provisions imposed no legal obligations upon persons having unregistered interests. Nevertheless, it is argued that the combination of features referred to preclude one who omitted to take the available steps from complaining of any resultant loss. The reasoning of the Commissioners on Real Property supports this view. The inadequacies of the caveat machinery may well merit attention, ${ }^{107}$ but that machinery is to be found in all of the Acts being discussed and its apparent function is surely that seen by the Commissioners in $1830,{ }^{108}$ Turgeon J. in Hackworth v. Baker, ${ }^{109}$ and other judges. ${ }^{110}$

Nevertheless, it may be argued that insistence upon notification or final registration in order to obtain protection against the possibility of later registration of an adverse interest would produce grave hardship, for example, where the prior interest taker does not have time to notify before the later interest taker becomes registered or where the prior interest taker is not legally, or properly advised. In partial answer to the first point it may be said that a prior interest taker can hardly be heard to say that he had not had sufficient time to take action to protect himself when a later interest taker had actually found time to take the necessary steps. In answer to the second point it may be asked what responsibility the later interest taker has for the quality of legal advice obtained by the prior claimant? Unless there is some demonstrable connection surely the prior claimant must suffer the loss occasioned by his own failure to obtain adequate guidance? Perhaps the suggestion of the Commissioners that an action for damages should be pursued against (a) a vendor or mortgagor who fraudulently defeats his own grant by subsequent conveyance, (b) an heir, devisee, or voluntary grantee of such a vendor or mortgagor, and (c) a purchaser or mortgagor who had actual knowledge, would be the answer. ${ }^{111}$ It would deter people from purchasing

\footnotetext{
104 Supra, n. 2.

103 Supra, n. 98, at 79 .

106 Supra, at $117 \cdot 119$.

107 Warrington Taylor, Land Transfer Reform, The Safeguarding of Documents Between Searching and Registration, [1963] N.Z.L.J. 568; Interim Registration, [1964] N.Z.L.J. 344; Hinde, supra, n. 98 at $125-127$.

10. Supra, at 121.

${ }^{109}$ Supra, at 118, n. 74

110 Supra, at 117 , nn. 70, 71

iil Second Report at 41-42.
} 
or taking securities on property over which there are unregistered interests of which notice has been acquired. It might at the same time not detract from the security of title afforded by the system by encouraging people acquiring interests to omit to effect notification. But the threat of such an action might well be sufficient in practice to produce a similar result to that produced by allowing the doctrine of notice to be used to defeat the proprietary interest of a registered owner. That is to say, it might produce sufficient uncertainty in the minds of prospective purchasers to negate the advantages otherwise offered by the system.

The situation in which the hardship or injustice arguments appear most telling is that where the registered proprietor had knowledge of the existence of the prior unregistered interest even before he acquired his equitable interest preparatory to perfecting his legal title by registration. It seems easier, where notice is acquired only after that date, to say that steps taken to obtain registration in a hurry should be permitted to achieve this object. No reliance could ever be placed on the register otherwise. But in the former situation it may be argued that the registered proprietor who commenced a transaction with knowledge of the existence of a prior equitable interest could not in truth say that he was relying on the state of the register. He already knew otherwise. However, the effect of allowing his registration to be defeated because of his knowledge of the prior interest and of the fact that his registration will defeat it, will again act to some extent to permit and encourage persons taking interests to refrain from placing notification on the register book. Also it would leave alive the problems associated with proof and disproof of notice referred to by the Commissioners on Real Property in their 1830 Report. ${ }^{112}$

For these reasons then it is submitted that notice should not be allowed to affect the title of a registered proprietor no matter when that notice was acquired. It is urged that the Acts under discussion provide that that shall in fact be the case. Furthermore, it is conceded that many of the cases looked at show that this view has been adopted in a number of jurisdictions. However it is clear that a strikingly different attitude has been taken in some other jurisdictions. For that reason, and because it is by no means impossible for a reversal of attitude to take place, the problem still seems worthy of discussion, even in Canada.

It also must be conceded that even if the above submissions are accepted problems still remain. In no jurisdiction is it likely that it would be considered palatable that fraudulent conduct should be rewarded. There will, therefore, always remain the "fraud" exception. Notice of prior interests will invariably be a constituent element of fraud. The problem of predicting what factors additional to notice will be sufficient to constitute fraud will also, therefore, remain. It is hardly possible nor desirable that fraud be exhaustively defined so the element of doubt will stay with us. In order, however, to prevent courts more conscious of the old equitable doctrines than of the positive benefits of a system of secure, readily discoverable title from

112 Supra, n. 87. 
emasculating the Torrens system it may be desirable to negatively define actual fraud so as to clearly exclude from its ambit registration in the face of and with the intention of defeating prior unregistered interests provided that no positively dishonest actions are resorted to in order to obtain registration.

Whether or not the foregoing submissions are accepted as embodying the most desirable policy to be implemented in a system of registered title, it is suggested that the approach taken in New Zealand and leaned toward in some of the provinces of Western Canada is a bad one in the light of the provisions at present in existence. That approach is difficult to reconcile with the words of the section itself and takes little or no account of the protection afforded by the present caveat machinery. It is not the main purpose of the Acts to ensure that frauds of various hues are not perpetrated. The purpose of the Acts as asserted before is surely to achieve certainty of title and to facilitate dealings in land. Fraud in the form of active trickery should not be rewarded but the Acts should be approached from the standpoint of achieving first and foremost the afore-mentioned purpose.

As Mr. Baalman has written, "the Torrens system is not just a novel form of land registration which has been superimposed on common law conveyancing, but an administrative philosophy in its own right."113 